\title{
Version of Femoral Neck: A Cadaveric Dried Bone Study
}

\author{
Versión del Cuello Femoral: Estudio Cadavérico sobre Huesos Secos
}

\author{
Kimaporn Khamanarong*; Wiphawi Hipkaeo"; Piyawan Chatuparisute**; \\ Surachai Sae-Jung* \& Kaewjai Tepsutamarat ${ }^{* * *}$
}

KHAMANARONG, K.; HIPKAEO, W.; CHATUPARISUTE, P.; SAE-JUNG, S. \& TEPSUTAMARAT, K. Version of femoral neck: a cadaveric dried bone study. Int. J. Morphol., 32(2):464-468, 2014.

SUMMARY: The aim of this study was to measure the version of femoral neck on dried Thai human femora. The version of femoral neck varies widely. It is important to know the version of femoral neck in a particular population to undertake successful femoral neck reconstructive surgery. Paired 216 dried femora of adult Thais from the bone collection maintained in the Department of Anatomy at the Faculty of Medicine, Khon Kaen University, Thailand, were used to measure the version of femoral neck. The mean+SD femoral anteversion (FNA) was 16.21+5.24 degrees. The 95\% confidence interval of FNA was from 15.48 to 16.94 degrees. The $95 \%$ confidence intervals of male and female average FNA were 14.75 to 16.90 and 15.59 to 17.59 degrees respectively. There was no significance difference of the FNA between males and females in both anteversion and retroversion groups. The average male FNA showed no statistical difference to average female anteversion. The $95 \%$ confidence intervals of males and females average retroversion were -8.22 to -4.80 and -7.71 to -4.47 degrees respectively. The average male retroversion showed no statistical difference to average female retroversion. The overall $95 \%$ confidence interval of femoral neck anteversion and retroversion were 15.48 to 16.94 degrees and -7.33 to -5.27 with no significant difference between males and females. These degrees of FNA must be considered when the femoral neck reconstructive surgery is planned.

KEY WORDS: Version femoral neck; Dried femora; Reconstructive surgery.

\section{INTRODUCTION}

Femoral neck anteversion (FNA) is defined as the angle between an imaginary transverse line that reference to bicondylar plane of the distal end of the femur and an imaginary transverse line passing through the center of the femoral head and neck (Fabry et al., 1973). Anteversion occurs when the axis of the neck inclines forward to the transcondylar plane but if it points posterior to the transcondylar plane it is known as retroversion. FNA may occur due to medial rotation of the limb bud during early intrauterine life, which gradually lessens during the postnatal period (Staheli, 1980). In postnatal development, a reduction of the FNA usually occurs during growth (Staheli; Fabeck et $a l$. , 2002). Between 3 and 12 months of age, the FNA average value is 39 degrees reaching a value close to 16 degrees at adult life (Dunlap et al., 1953). The FNA has important implications in various corrective osteotomies as well as in hip arthroplasties (Shrikant et al., 2009). Previous studies have used various methods to measure the FNA, namely measuring the FNA mechanically on cadaveric bones (Kate \& Robert,
1963; Yoshioka et al., 1987) as well as in patients by using roentgenography (Ruby et al., 1979), ultrasound (Lausten et al., 1989), computerized tomography (Lausten et al.), or MRI (Schneider et al., 1997). The Kingsley \& Olmsted (KO) method has been used various researchers and is considered to be the most accurate method (Kingsley \& Olmsted, 1948). The FNA varies widely, and it is important to know the FNA in a particular population to undertake the successful femoral neck reconstructive surgery for instance. This project was undertaken with the aim to measure the angle of version on dried human femora from Thais.

\section{MATERIAL AND METHOD}

Paired 216 Thai dried adult femora from the bone collection maintained in the Department of Anatomy at the Faculty of Medicine, Khon Kaen University, Thailand, were

\footnotetext{
* Department of Anatomy, Faculty of Medicine, KhonKaen University, KhonKaen, Thailand.

** Department of Orthopaedics, Faculty of Medicine, KhonKaen University, KhonKaen, Thailand.

*** Division Research, Faculty of Medicine, KhonKaen University, KhonKaen, Thailand.
} 
included in the study. Those of unknown age and sex were excluded from this study. All bones were well preserved and had no gross pathology. The age and sex of the deceased were recorded. The femora examined in this study belonged to 108 men $(25$ to 75 years, mean + SD $60.08+14.88$ years), and 108 women (28 to 75 years, mean+SD 58.08+16.30 years). All of the dried femora came from individuals who had donated their bodies to the Department.

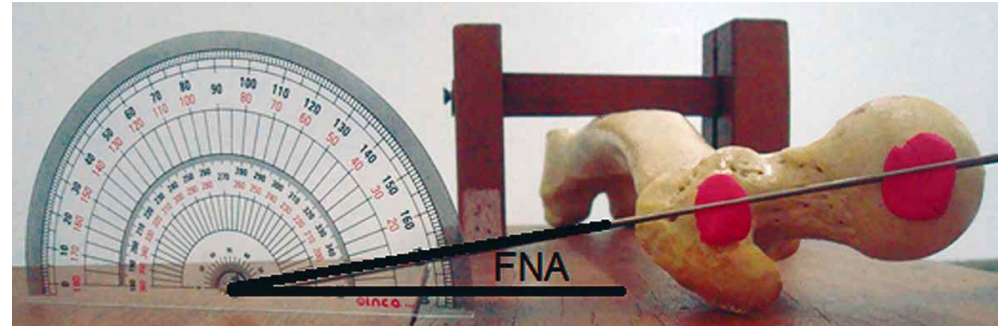

Fig. 1. The KO (Kingsley \& Olmsted) method of FNA measurement. The FNA is between the center head neck line and transcondylar line.
The FNA was measured by the KO method. The femora were placed horizontally on the table to ensure that the condyles of the inferior end rested on the table surface. The FNA was measured using a protractor to estimate the femoral anteversion angle (Fig. 1).

Three measurements were taken for each bone, and the average was recorded. Data were collected, tabulated and statistically analyzed. All continuous data were reported as mean and standard deviation (SD) and sex comparisons were analyzed statistically by the independent sample t-test. The study was approved by the Research and Ethics Committee of the Faculty of Medicine, KhonKaenUniversity.

\section{RESULTS}

As shown in Table I, the mean+SD of femoral neck anteversion angle was $16.21+5.24$ degrees. The $95 \%$ confidence interval of femoral neck anteversion was from 15.48 to 16.94 degrees. The $95 \%$ confidence intervals of male and female average anteversion were 14.75 to 16.90 and 15.59 to 17.59 degrees respectively (Fig. 2). There was no significant FNA difference between males and females in both anteversion and retroversion (Figs. 3 and 4). The average male FNA showed no statistical difference to the average female anteversion (mean difference $-0.76, \mathrm{p}=0.305$ ). Retroversion

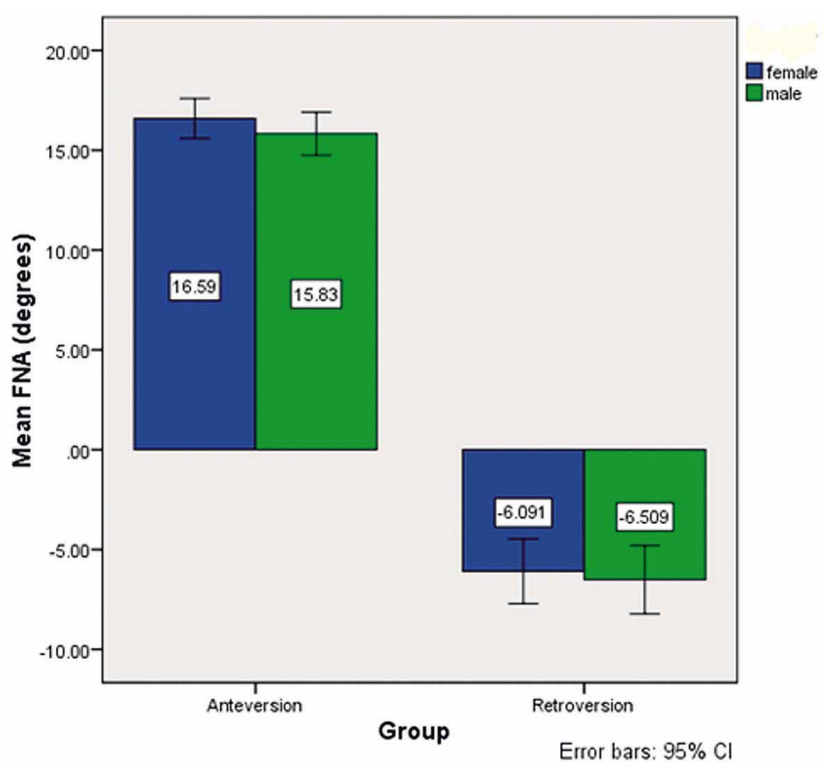

Fig. 2. The bar graphs demonstrate the FNA and 95\% CI of FNA according to sex. There were no statistical differences between male and female femoral neck anteversion $(\mathrm{p}=0.305)$ and femoral neck retroversion $(\mathrm{p}=0.682)$.

was observed in 32 bones (27.59\%), the $95 \%$ confidence intervals of male and female average retroversion were -8.22 to -4.80 and -7.71 to -4.47 degrees respectively. The average male retroversion showed no statistical difference to the average female retroversion (mean difference $-0.42, \mathrm{p}=0.682$ ).

Table I. The mean+SD of FNA (degrees).

\begin{tabular}{lcccccc}
\hline & \multicolumn{3}{c}{ Anteversion $(\mathbf{n = 2 0 0})$} & \multicolumn{3}{c}{ Retroversion (n=16) } \\
\cline { 2 - 6 } & Left side & Right side & Average & Left side & Right side & Average \\
\hline Male (n=108) & $16.18 \pm 5.62$ & $15.47 \pm 5.94$ & $15.83 \pm 5.42$ & $-5.44 \pm 1.43$ & $-7.58 \pm 3.12$ & $-6.51 \pm 2.05$ \\
95\% CI & 15.06 & 14.30 & 14.75 & -6.63 & -10.19 & -8.22 \\
Male & 17.29 & 16.65 & 16.90 & -4.24 & -4.97 & -4.80 \\
Female (n=108) & $16.65 \pm 5.87$ & $16.53 \pm 6.06$ & $16.59 \pm 5.05$ & $-6.41 \pm 2.78$ & $-5.77 \pm 1.47$ & $-6.09 \pm 1.94$ \\
95\% CI & 15.49 & 15.33 & 15.59 & -8.74 & -7.00 & -7.71 \\
Female & 17.81 & 17.73 & 17.59 & -4.08 & -4.54 & -4.47 \\
Total & $16.41 \pm 5.74$ & $16.00 \pm 6.00$ & $16.21 \pm 5.24$ & $-5.92 \pm 2.20$ & $-6.68 \pm 2.53$ & $-6.30 \pm 1.94$ \\
95\% CI & 15.61 & 15.16 & 15.48 & -7.10 & -8.03 & -7.33 \\
Total & 17.21 & 16.94 & 16.94 & -4.75 & -5.33 & -5.27 \\
\hline
\end{tabular}




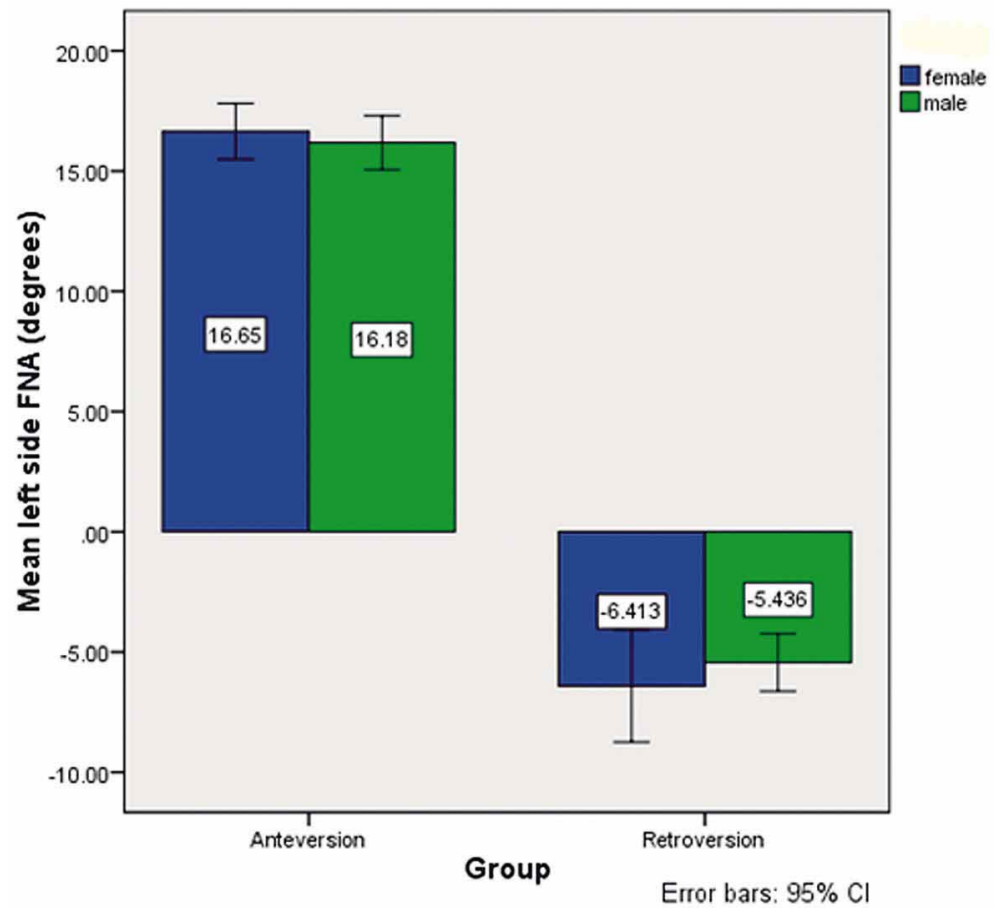

Fig. 3. The bar graph demonstrates the left side FNA and 95\% CI of left side FNA according to sex. There were no statistical differences between male and female left side anteversion $(\mathrm{p}=0.563)$ and left side retroversion $(\mathrm{p}=0.393)$.

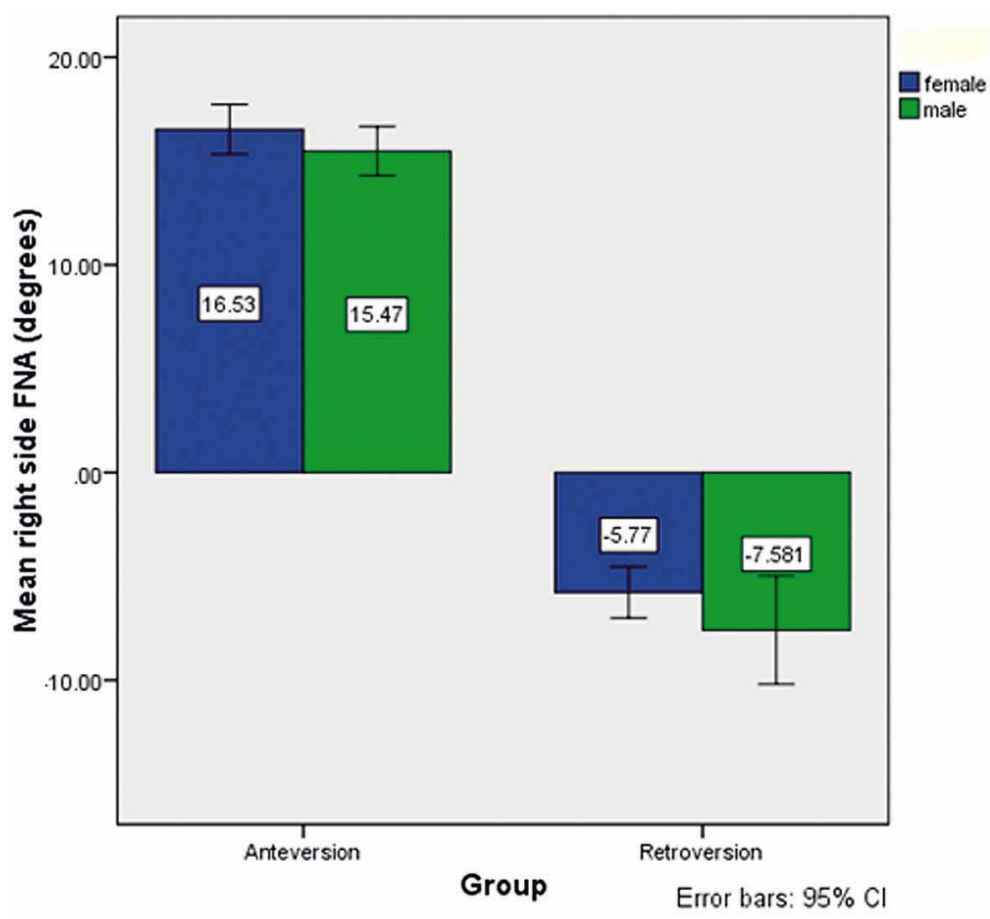

Fig. 4. The bar graph demonstrates the right side FNA and 95\% CI of right side FNA according to sex. There were no statistical differences between male and female right side anteversion $(\mathrm{p}=0.216)$ and right side retroversion $(\mathrm{p}=0.160)$.

\section{DISCUSSION}

A knowledge of normal FNA is important for orthopaedic diagnosis and for selection of patients and planning before derotation osteotomy of femurs (Ruwe et al., 1992; Nagar et al., 2000) especially in a particular population. Restoration of FNA is important in achieving stability of the prosthetic joints (Schneider et al.). Although newer methods using computerized tomography (CT) (Lausten et al.) have been developed, there is no universal consensus for locating the femoral neck axis and the femoral condylar axis (Murphy et al., 1987). Hence, estimation of anteversion on dry bone is still considered the most accurate method. Various methods have been used by researchers to determine the FNA, and wide variation has been documented for the mean FNA. The source of variation may be the precise location of the central axis (Jain et al., 2003). Researchers have examined the average anteversion in a normal population by direct observation on dry bones, and found it has a wide range from -25 degrees to +50 degrees in adults, with a mean FNA from 8 $28^{\circ}$ (Dunlap et al.; Kingsley \& Olmsted; Maheshwari et al., 2004; Srimathi et al., 2012; Zalawadia et al., 2010). Kingsley \& Olmsted reported the mean FNA as 8.021 degrees, whereas the mean determined by the KO method in our study was 16.21 degrees, which is not close to that of the Kingsley \& Olmsted report. Kingsley \& Olmsted calculated only the mean, and no standard deviation was documented. The mean alone is not sufficient to determine the true distribution of the angle of anteversion in a total set of bones. No statistical difference was found for the femoral anteversion between male-type bones and the right-and left-sided bones in our study. Zalawadia et al. documented anteversion to be greater in females (with mean anteversion in females compared to males being13.6 and 10.9 degrees respectively). Kingsley \& Olmsted found a negligible difference ( 0.081 degree) whereas Yoshioka et al., found a difference of 1 degree. However, no tests of significance were done in these studies. Racial differences in FNA have been described (Zalawadia et al.). Femoral anteversion have been studied in skeletal surveys by other researchers shown as Table II.

The average FNA has been reported to be 11.4 to 19.8 degrees by CT (Sugano et al., 
KHAMANARONG, K.; HIPKAEO, W.; CHATUPARISUTE, P.; SAE-JUNG, S. \& TEPSUTAMARAT, K. Version of femoral neck: a cadaveric dried bone study. Int. J. Morphol., 32(2):464-468, 2014.

Table II. The racial differences of the FNA

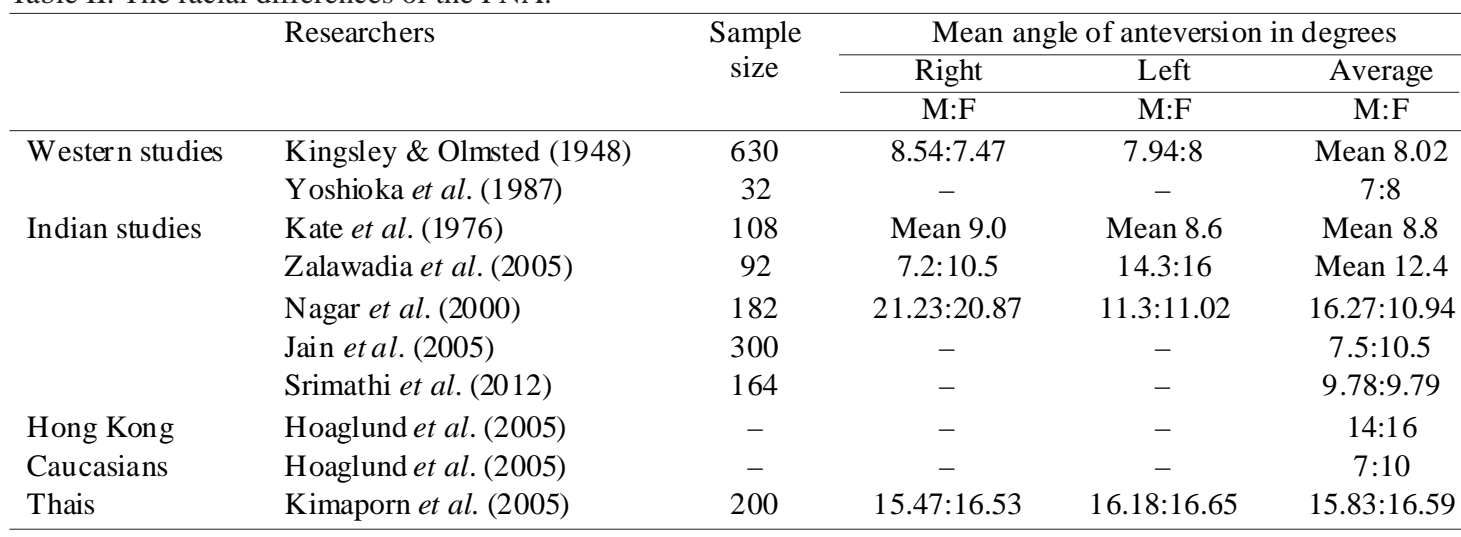

1998; Hermann et al., 1998), and 15 to 28 degrees by various biplanar X-ray techniques based on specimens and living subjects (LaGasse et al., 1998). Braten et al. (1992) found the average anteversion to be 18 degrees in normal females and 14 degrees in normal males using ultrasound.

Femoral neck anteversion is important in reconstructive surgery such as total hip arthroplasty, and many research have been undertaken in order to develop the optimal orientation of the hip prosthesis. Some studies advocated the anteversion of the prosthesis of 10 to 15 degrees in achieve optimal hip stability together with optimal range of motion (Tayton, 2007), while Charnley (1970) favored 0 degree to enhance the stability of the arthroplasty. Tayton described that femoral neck anteversion is a result of forces acting through the hip during daily activities. The FNA may vary upon the different cultures or daily activities of the patients. In a reconstructive surgery of the hip, especially the femoral stem replacement in hemiarthroplasty surgery, we recommend to set the femoral neck anteversion to their normal anteversion (15-17 degrees). However, we also recommend investigating the contralateral side anteversion for the preoperative planning in a case that the affected side cannot be evaluated for its version.

\section{CONCLUSION}

The respective overall 95\% confidence interval of femoral neck anteversion and retroversion were 15.48 to 16.94 degrees and -7.33 to -5.27 with no significant difference between males and females in a Thai population. These degrees of FNA must be considered when the femoral neck reconstructive surgery is planned such as in corrective osteotomy or in hip arthroplasty. However, the retroversion of FNA which was also found in small number of cases in our study, suggest that it is important to conduct a thorough preoperative investigation of the femoral neck version for patients who will undergo operations on their femoral heads and necks.

\section{ACKNOWLEDGEMENTS}

We gratefully acknowledge(a) the many Thais who donate their body to Department of Anatomy, Faculty of Medicine and their families for granting permission (b) the staff in the Bone Museum in the Department of Anatomy and (c) the support of the Khon Kaen University Publication Clinic, Research and Technology Transfer Affairs, Khon Kaen University,for their assistance with the Englishlanguage presentation of the manuscript (d) a grant from the Faculty of Medicine, Khon Kaen University, Khon Kaen, Thailand.

KHAMANARONG, K.; HIPKAEO, W.; CHATUPARISUTE, P.; SAE-JUNG, S. \& TEPSUTAMARAT, K. Versión del cuello femoral: estudio cadavérico sobre huesos secos. Int. J. Morphol., 32(2):464-468, 2014.

RESUMEN: El objetivo fue medir el cuello femoral en fémures humanos de tailandeses adultos. La versión del cuello femoral es muy variable. Es importante conocer la versión de cuello femoral en una población en particular para llevar a cabo con éxito una cirugía reconstructiva. Se utilizaron 216 fémures secos de adultos tailandeses obtenidos de la colección del Departamento de Anatomía de la Facultad de Medicina de la Universidad de Khon Kaen, Tailandia. La anteversión femoral (AFM) media+DE fue de $16,21 \pm 5,24^{\circ}$. El intervalo de confianza del $95 \%$ de la AFM fue entre $15,48^{\circ}$ a $16,94^{\circ}$. El promedio de intervalos de confianza del $95 \%$ en hombres y mujeres fue desde $14,75^{\circ}$ a $16,90^{\circ}$ y $15,59^{\circ}$ a $17,59^{\circ}$, respectivamente. No hubo diferencia significativa entre hombres y mujeres en ambos grupos de anteversión y retroversión. La AFM promedio en hombres no mostró diferencia significativa con la anteversión media de las mujeres. Se observó un promedio 
de $-8,22^{\circ}$ a $-4,80^{\circ}$ y $-7,71^{\circ}$ a $-4,47^{\circ}$ en el $95 \%$ de los intervalos de confianza entre hombres y mujeres, respectivamente. La retroversión promedio en hombres no mostró ninguna diferencia significativa con la retroversión media en las mujeres. Estos grados de AFM deben ser considerados en la planificación de una cirugía reconstructiva del cuello femoral.

PALABRAS CLAVE: Cuello femoral versión; Fémures secos; Cirugía reconstructiva.

\section{REFERENCES}

Bråten, M.; Terjesen, T. \& Rossvoll, I. Femoral anteversion in normal adults. Ultrasound measurements in 50 men and 50 women. Acta Orthop. Scand., 63(1):29-32, 1992.

Charnley, J. Total hip replacement by low-friction arthroplasty. Clin. Orthop. Relat. Res., 72:7-21, 1970.

Dunlap, K.; Shands, A. R. Jr.; Hollister, L. C. Jr.; Gaul, J. S. Jr. \& Streit, H. A. A new method for determination of torsion of the femur. J. Bone Joint Surg. Am., 35-A(2):289-311, 1953.

Fabeck, L.; Tolley, M.; Rooze, M. \& Burny, F. Theoretical study of the decrease in the femoral neck anteversion during growth. Cells Tissues Organs, 171(4):269-75, 2002.

Fabry, G.; MacEwen, G. D. \& Shands, A. R. Jr. Torsion of the femur. A follow-up study in normal and abnormal conditions. J. Bone Joint Surg. Am., 55(8):1726-38, 1973.

Hermann, K. L. \& Egund, N. Measuring anteversion in the femoral neck from routine radiographs. Acta Radiol., 39(4):410-5, 1998.

Jain, A. K.; Maheshwari, A. V.; Nath, S.; Singh, M. P. \& Nagar, M. Anteversion of the femoral neck in Indian dry femora. J. Orthop. Sci., 8(3):334-40, 2003.

Kate, B. R. \& Robert, S. L. The angle of femoral torsion. J. Anat. Soc. India, 12:8-11, 1963.

Kingsley, P. C. \& Olmsted, K. L. A study to determine the angle of anteversion of the neck of the femur. J. Bone Joint Surg. Am., 30A(3):745-51, 1948.

LaGasse, D. J. \& Staheli, L. T. The measurement of femoral anteversion. A comparison of the fluoroscopic and biplane roentgenographic methods of measurement. Clin. Orthop. Relat. Res., 86:13-5, 1972.

Lausten, G. S.; Jørgensen, F. \& Boesen, J. Measurement of anteversion of the femoral neck. Ultrasound and computerised tomography compared. J. Bone Joint Surg. Br., 71(2):237-9, 1989.

Maheshwari, A. V.; Jain, A. K.; Singh, M. P. \& Bhargava, S. K. Estimation of femoral neck anteversion in adults - A comparison between peroperative, clinical and biplane X-rays methods. Indian J. Orthop., 38(3):151-7, 2004.
Murphy, S. B.; Simon, S. R.; Kijewski, P. K.; Wilkinson, R. H. \& Griscom, N. T. Femoral anteversion. J. Bone Joint Surg. Am., 69(8):1169-76, 1987.

Nagar, M.; Bhardwaj, R. \& Prakash, R. Anteversion in adult Indian femora. J. Anat. Soc. India, 49(1):9-12, 2000.

Ruby, L.; Mital, M. A.; O'Connor, J. \& Patel, U. Anteversion of the femoral neck. J. Bone Joint Surg. Am., 61(1):46-51, 1979.

Ruwe, P. A.; Gage, J. R.; Ozonoff, M. B. \& DeLuca, P. A. Clinical determination of femoral anteversion. A comparison with established techniques. J. Bone Joint Surg. Am., 74(6):820-30, 1992.

Schneider, B.; Laubenberger, J.; Jemlich, S.; Groene, K.; Weber, H. M. \& Langer, M. Measurement of femoral antetorsion and tibial torsion by magnetic resonance imaging. Br. J. Radiol., 70(834):575-9, 1997.

Shrikant, A. R.; Arati, K. M. \& Sant, S. M. The angle of femoral anteversion in indians. J. Anat. Soc. India, 58(2):161-5, 2009.

Srimathi, T.; Muthukumar, T.; Anandarani, V. S.; Umapathy, S. \& Rameshkumar, S. A study on femoral neck anteversion and its clinical correlation. J. Clin. Diagn. Res., 6(2):155-8, 2012.

Staheli, L. T. Medial femoral torsion. Orthop. Clin. North. Am., 11(1):39-50, 1980.

Sugano, N.; Noble, P. C. \& Kamaric, E. A comparison of alternative methods of measuring femoral anteversion. J. Comput. Assist. Tomogr., 22(4):610-41, 1998.

Tayton, E. Femoral anteversion: a necessary angle or an evolutionary vestige? J. Bone Joint Surg. Br., 89(10):1283-8, 2007.

Yoshioka, Y.; Siu, D. \& Cooke, T.D. The anatomy and functional axes of the femur. J. Bone Joint Surg. Am., 69(6):873-80, 1987.

Zalawadia, A.; Ruparelia, S.; Shah, S.; Parekh, D.; Patel, S.; Rathod, S. P. \& Patel, S. V. Study of femoral neck anteversion of adult dry femora in gujarat region. Natl. J. Integr. Res. Med., 1(3):7$11,2010$.

Correspondence to:

K. Khamanarong

Department of Anatomy,

Faculty of Medicine,

KhonKaen University,

KhonKaen 40002

THAILAND

Email: kkimap@kku.ac.th 